\title{
IMPLEMENTASI PROGRAM PENGEMBANGAN USAHA MINA PEDESAAN PENGOLAHAN DAN PEMASARAN HASIL PERIKANAN (PUMP-P2HP) TAHUN 2014 DI KABUPATEN TRENGGALEK
}

\author{
Implementation Of Rural Fisheries Businesses Program-Processing And Marketing Of Fisheries \\ Product (PUMP-P2HP) 2014 In Trenggalek Regency
}

\author{
Sari Puspitorini ${ }^{1}$ \\ ${ }^{1}$ Magister Ilmu Administrasi Universitas Kadiri
}

\begin{abstract}
Abstrak
Program PUMP-P2HP merupakan program pengentasan kemiskinan berbasis pemberdayaan masyarakat melalui fasilitasi bantuan pengembangan usaha bagi pengolah dan pemasar hasil perikanan dalam wadah Kelompok Pengolah dan Pemasar ( POKLAHSAR ). Tujuan Penelitian ini adalah untuk mendeskripsikan dan menganalisis implementasi Program PUMP-P2HP Tahun 2014 di Kabupaten Trenggalek dan faktorfaktor penghambat dan pendukung implementasi Program PUMP-P2HP 2014 di Kabupaten Trenggalek. Penelitian ini menggunakan metode kualitatif diskriptif, sementara pengumpulan data primer melalui wawancara dan observasi, sedangkan pengumpulan data sekunder melalui studi pustaka. Hasil Penelitian menunjukkan hasil sebagai berikut: 1) Implementasi Program PUMP-P2HP Tahun 2014 di Kabupaten Trenggalek sudah mengacu kepada 6 elemen pemberdayaan yaitu pendampingan, partisipasi komunitas, pengorganisasian kelompok, transparansi, sistem pengawasan dan perspektif gender; (2) Faktor pendukung keberhasilan Program PUMP-P2HP Tahun 2014 di Kabupaten Trenggalek antara lain komunikasi dan koordinasi yang baik antar pelaksana kebijakan, Sumber Daya Manusia yang bisa diandalkan dan anggaran yang memadai; 3) Faktor penghambat keberhasilan Program PUMP-P2HP Tahun 2014 di Kabupaten Trenggalek antara lain adanya proses identifikasi dan verifikasi kelompok baru pengganti kelompok aspirasi, sehingga menyebabkan tahap pengusulan sampai dengan pencairan ikut mundur.
\end{abstract}

Kata Kunci: Implementasi; PUMP-P2HP; Pemberdayaan Masyarakat

\begin{abstract}
The PUMP-P2HP Program is a community-based poverty reduction program through the facilitation of business development assistance for processors and marketers of fishery products within the Processing Group and Marketers (POKLAHSAR). The purposes of this study were to describe and to analyze the Implementation of PUMP-P2HP Program 2014 in Trenggalek Regency and factors that support or inhibit PUMP-P2HP Program. This research uses qualitative descriptive method, while collecting primary data through interview and observation, while collecting secondary data from literatures. The results of the research showed that : 1) the Implementation of PUMP-P2HP Program in 2014 in Trenggalek Regency has been referring to 6 elements of empowerment that is mentoring, community participation, group organizing, transparency, monitoring system and gender perspective; 2) Supporting success factors of the Implementation of PUMP-P2HP Program 2014 in Trenggalek Regency including good communication and coordination between the implementors, qualified human resources and adequate budget, 3) The inhibiting success factors of the PUMP-P2HP Program 2014 in Trenggalek Regency including the identification and verification of new groups for substitution of aspiration groups, causing the proposing stage up to the withdrawal.
\end{abstract}

Keywords: Implementation; PUMP-P2HP; Empowerment

\section{A. PENDAHULUAN}

Pemberdayaan ekonomi rakyat merupakan salah satu upaya pengentasan kemiskinan. Perekonomian rakyat merupakan indikator keberhasilan pembangunan serta menjadi sasaran penting yang akan menentukan keberhasilan pembangunan di bidang lainnya. Diantara upaya yang dilakukan Pemerintah dalam 
rangka memberdayakan perekonomian rakyat adalah pengelolaan sektor perikanan.

Pengentasan kemiskinan di wilayah pesisir dan sentra-sentra perikanan merupakan salah satu kegiatan strategis dalam pelaksanaan pembangunan kelautan dan perikanan. Kemiskinan yang terjadi pada masyarakat kelautan dan perikanan merupakan salah satu masalah pokok nasional yang penanggulangannya harus menjadi prioritas utama dalam pelaksanaan pembangunan kelautan dan perikanan. Untuk meningkatkan efektivitas penanggulangan kemiskinan dan penciptaan lapangan kerja, pada tahun 2007 pemerintah di bawah koordinasi Kementerian Koordinator Kesejahteraan Rakyat telah meluncurkan Program Nasional Pemberdayaan Masyarakat (PNPM) Mandiri. Sejak tahun 2009 di bawah payung Program Nasional Pemberdayaan Masyarakat (PNPM) Mandiri, Kementerian Kelautan dan Perikanan telah melaksanakan PNPM Mandiri Kelautan dan Perikanan sebagai PNPM sektoral atau pendukung dengan target sasaran karakteristik kelompok usaha tertentu. Mulai tahun 2011 PNPM Mandiri Kelautan dan Perikanan dilakukan melalui 3 komponen yaitu Pengembangan Usaha Mina Pedesaan Perikanan Tangkap (PUMP-PT), Perikanan Budidaya (PUMPPB), Pengolahan dan Pemasaran Hasil Perikanan (PUMP-P2HP), Pemberdayaan Usaha Garam Rakyat (PUGAR) serta Pengembangan Desa Pesisir Tangguh (PDPT). Program Pengembangan Usaha Mina Pedesaan Pengolahan dan Pemasaran Hasil Perikanan ( PUMP-P2HP ) merupakan kegiatan pemberdayaan masyarakat melalui fasilitasi bantuan pengembangan usaha bagi pengolah dan pemasar hasil perikanan yang juga merupakan UMKM perikanan dalam wadah Kelompok Pengolah dan Pemasar ( POKLAHSAR ). POKLAHSAR adalah kelompok usaha kelautan dan perikanan bidang pengolahan dan pemasaran sebagi target sasaran PUMP P2HP. Dengan adanya Program PUMP-P2HP, diharapkan dapat meningkatkan pendapatan POKLAHSAR dan menyerap tenaga kerja baru bidang pengolahan dan pemasaran.
Kabupaten Trenggalek sudah menerima paket Bantuan Langsung Masyarakat (BLM) dari program PUMPP2HP sebanyak 4 periode mulai tahun 2011 2014 dengan rincian sebagai berikut :

Tabel 1. Penerima BLM Program PUMP P2HP di Kabupaten Trenggalek Tahun 2011 - 2014

\begin{tabular}{|c|c|c|}
\hline No & Tahun & $\begin{array}{c}\text { Jumlah } \\
\text { POKLAHSAR }\end{array}$ \\
\hline 1. & 2011 & 8 \\
\hline 2. & 2012 & 11 \\
\hline 3 & 2013 & 7 \\
\hline 4. & 2014 & 5 \\
\hline \multicolumn{2}{|c|}{ TOTAL } & 31 \\
\hline
\end{tabular}

Rumusan masalah penelitian ini sebagai berikut:

1. Bagaimana Implementasi Program Pengembangan Usaha Mina Pedesaan Pengolahan dan Pemasaran Hasil Perikanan ( PUMP-P2HP) Tahun 2014 di Kabupaten Trenggalek?

2. Faktor-faktor Penghambat dan Pendukung apa sajakah dalam implementasi Program PUMP-P2HP 2014 di Kabupaten Trenggalek tersebut?

\section{B. LANDASAN TEORITIS}

\subsection{Implementasi Kebijakan Publik}

Implementasi kebijakan menurut Nugroho (2008:432) pada dasarnya adalah cara agar sebuah kebijakan dapat mencapai tujuannya. Untuk mengimplemetasikannya, setidaknya ada dua pilihan langkah yang ada, yaitu langsung mengimplementasikan dalam bentuk program atau melalui formulasi kebijakan derivate atau turunan dari kebijakan publik tersebut. Lester dan Stewart dalam Winarno, (2002:101-102) menyatakan bahwa, "implementasi kebijakan dipandang dalam pengertian luas merupakan alat administrasi hukum dimana berbagai aktor, organisasi, prosedur dan teknik yang bekerja bersama-sama untuk menjalankan kebijakan guna meraih dampak atau tujuan yang diinginkan".

Sifat implementasi suatu kebijakan lebih menunjukkan pada luas jangkauan kebijakan atau untuk siapa kebijakan itu berlaku. 
Menurut Sadhana (2013 : 171) unsur-unsur dari implementasi kebijakan yang mutlak harus ada yaitu : 1) Unsur pelaksana, 2) Adanya program yang dilaksanakan serta 3) Target grup atau kelompok sasaran.

Fungsi implementasi menurut Wahab, 1990 dalam Sadhana (2013 : 183) adalah untuk membentuk suatu hubungan yang memungkinkan tujuan-tujuan ataupun sasaran kebijakan negara diwujudkan sebagai "out come" dari kegiatan-kegiatan yang dilakukan pemerintah. Implementasi Kebijakan merupakan aspek yang penting dari keseluruhan proses kebijakan.

Dengan demikian dapat disimpulkan bahwa implementasi merupakan proses mengeksekusi konsep / ide (transformasi rumusan-rumusan) secara konsekutif ke dalam fase-fase kegiatan dengan memanfaatkan berbagai sumber daya (alam, manusia maupun biaya) yang dikelola dan didistribusi dalam pola koordinasi, komunikasi yang akurat, clearly dan konsisten untuk mencapai tujuan yang telah ditetapkan.

\subsection{Konsep Pemberdayaan Masyarakat}

Menurut Kartasamita (1996:144)

memberdayakan mengandung pengertian sebagai berikut : Upaya memperkuat unsurunsur kebudayaan untuk meningkatkan harkat dan martabat lapisan masyarakat yang dalam kondisi tidak mampu, hanya dengan mengandalkan kekuatan diri sendiri untuk melepaskan diri dari perangkap kemiskinan dan keterbelakangan. Jadi memberdayakan adalah memampukan dan memandirikan masyarakat. Dalam kerangka pikiran itu, upaya memberdayakan masyarakat haruslah pertama-tama dimulai dengan menciptkan suasana atau iklim yang memungkinkan potensi masyarakat berkembang. Disini titik tolaknya adalah pengenalan bahwa setiap manusia, setiap masyarakat, memiliki potensi yang dapat dikembangkan. Artinya, tidak ada masyarakat yang sama sekali tanpa daya, karena, kalau demikian akan sudah punah. Pemberdayaan adalah upaya untuk membangun daya itu, dengan mendorong, memotivasi dan membangkitkan kesadaran akan potensi yang dimilikinya serta berupaya untuk mengembangkannya.

Konsep pemberdayaan dalam wacana pembangunan masyarakat selalu dihubungkan dengan konsep mandiri, partisipasi, jaringan kerja dan keadilan. Pada dasarnya pemberdayaan diletakkan pada kekuatan tingkat individu dan sosial. Pemberdayaan merujuk pada kemampuan orang, khususnya kelompok rentan dan lemah sehingga mereka memiliki kekuatan atau kemampun dalam (a) memenuhi kebutuhan dasarnya sehingga mereka memiliki kebebasan (freedom) dalam arti bukan saja bebas dalam mengemukakan pendapat, melainkan bebas dari kelaparan, bebas dari kebidihan, bebas dari kesakitan; (b) menjangkau sumber-sumber produkstif yang memungkinkan mereka dapat meningkatkan pendapatannya dan memperoleh barang-barang dan jasa-jasa yang mereka perlukan; dan (c) berpartisipasi dalam proses pembangunan dan keputusankeputusan yang mempengaruhi mereka (Suharto, 2005).

\subsection{Pemberdayaan Masyarakat Pesisir}

Karekteristik masyarakat yang tinggal di kawasan pesisir, berbeda dengan masyarakat yang tinggal di daratan. Di beberapa kawasan pesisir yang relatif berkembang pesat, struktur masyarakatnya bersifat heterogen, memiliki etos kerja tinggi, solidaritas sosial yang kuat, serta terbuka terhadap perubahan dan interaksi sosial. Sekalipun demikian, masalah kemiskinan masih mendera sebagian masyarakat pesisir, sehingga fakta sosial ini terkesan ironi di tengah-tengah kekayaan sumber daya pesisir dan lautan ( Kusnadi, 2009).

Sebagai suatu proses pemberdayaan adalah serangkaian kegiatan untuk memperkuat kekuasaan atau keberdayaan kelompok lemah dalam masyarakat, termasuk individu-individu yang mengalami masalah kemiskinan. Sebagai tujuan, maka pemberdayaan menunjuk pada keadaan atau hasil yang ingin dicapai oleh sebuah perubahaan sosial, yaitu masyarakat yang berdaya, memiliki kekuasaan atau mempunyai kemampuan dan pengetahuan dalam memenuhi kebutuhan hidupnya baik 
yang bersifat fisik, ekonomi maupun sosial, seperti memiliki kepercayaan diri, mampu menyampaikan aspirasi, mempunyai mata pencaharian, berpartisipasi dalam kegiatan sosial, mandiri dalam melaksanakan tugastugas kehidupannya (Ife, 1995). Merujuk dari dua pendapat diatas tepat kiranya jika pemberdayaan masyarakat ditujukan kepada masyarakat pesisir.

Pembangunan di kawasan pesisir dan umumnya pembangunan perikanan dan kelautan, masalah kualitas SDM dan lingkungan sepatutnya mendapat perlakuan khusus, karena secara umum masyarakat pesisir memiliki pendidikan dan kesehatan yang masih rendah. Oleh karena itu dalam investasi SDM masyarakat pesisir sudah sepatutnya mempertimbangkan kedua hal tersebut. Adapun sasaran pemberdayaan masyarakat pesisir, diformulasikan sebagai berikut:

a. Terpenuhinya kebutuhan dasar manusia yang terdiri dari sandang, pangan, papan, kesehatan dan pendidikan.

b. Tersedianya prasarana dan sarana produksi lokal yang memungkinkan masyarakat dapat mengakses dengan harga murah dan berkualitas yang baik.

c.Meningkatnya peran kelembagaan masyarakat sebagai wadah aksi kolektif untuk mencapai tujuan tujuan individu.

d. Terciptanya kegiatan-kegiatan ekonomi produktif di daerah yang memiliki ciri-ciri berbasis sumberdaya lokal, pasar yang jelas, berkelanjutan berdasarkan kapasitas sumberdaya, dimiliki dan dilaksanakan serta berdampak bagi masyarakat lokal, dan dengan menggunakan teknologi maju tepat guna yang berasal dari proses pengkajian dan penelitian.

e. Terciptanya jaringan transportasi dan komunikasi yang memadai, sebagai basis jaringan ekonomi, baik antara kawasan pesisir maupun antara pesisir dan pedalaman. f. Terwujudnya struktur ekonomi Indonesia yang berbasis pada kegiatan ekonomi di wilayah pesisir dan laut sebagai wujud pemanfaatan dan pendayagunaan sumberdaya alam laut.

\subsection{Program Pengembangan Usaha Mina \\ Pedesaan Pengolahan dan \\ Pemasaran Hasil Perikanan ( PUMP- P2HP)}

PUMP-P2HP adalah bagian dari pelaksanaan program PNPM Mandiri KP dalam memberdayakan usaha mikro melalui stimulan bantuan pengembangan usaha sesuai dengan peluang usaha. Pola dasar PUMP-P2HP dirancang untuk meningkatkan kemampuan POKLAHSAR yang terdiri dari kelompok pengolah dan pemasar hasil perikanan untuk mengembangkan usaha produktif dalam rangka mendukung peningkatan kemampuan dan pengembangan wirausaha bidang pengolahan dan pemasaran.

\subsection{Kelompok Pengolah dan Pemasar (POKLAHSAR) Hasil Perikanan}

Menurut Peraturan Menteri Kelautan dan Perikanan (2010) pengolahan ikan yang selanjutnya disebut pengolahan adalah rangkaian kegiatan dan/atau perlakuan dari bahan baku ikan sampai menjadi produk akhir untuk konsumsi manusia. Selanjutnya dari pengertian tersebut berkembang definisi tentang pengolah dan pemasar hasil perikanan. Sedangkan menurut Keputusan Dirjen Pengolahan dan Pemasaran Hasil Perikanan ( 2014:8 ), pengolah adalah orang yang mata pencahariannya melakukan usaha pengolahan hasil perikanan. Sedangkan pemasar adalah orang yang mata pencahariannya melakukan kegiatan pemasaran hasil perikanan termasuk produk olahannya.

Ciri-ciri POKLAHSAR adalah (1) memiliki jumlah anggota minimal 5 orang, (2) pelaku utama yang berada di dalam lingkungan pengaruh seorang ketua kelompok, (3) mempunyai tujuan, minat dan kepentingan yang sama terutama di bidang pengolahan dan pemasaran hasil perikanan, (4) memiliki kesamaan dalam tradisi/kebiasaan, domisili, lokasi usaha, 
status ekonomi dan bahasa, (5) bersifat informal, (6) memiliki saling ketergantungan antar individu, (7) mandiri dan partisipatif, (8) memiliki aturan/norma yang disepakati bersama dan (9) memiliki administrasi yang rapi.

\section{METODE PENELITIAN}

Jenis penelitian yang digunakan adalah penelitian deskriptif dengan pendekatan kualitatif. Penelitian ini dilakukan di Kabupaten Trenggalek, terutama Kecamatan Watulimo, Panggul, Pogalan dan Kampak sebagai penerima manfaat Program PUMP-P2HP Tahun 2014.

\section{PEMBAHASAN}

4.1. Implementasi Program Pengembangan Usaha Mina Pedesaan Pengolahan dan Pemasaran Hasil Perikanan ( PUMP-P2HP ) Tahun 2014 di Kabupaten Trenggalek

\subsubsection{Pendampingan}

Pendampingan PUMP-P2HP Tahun 2014 dilaksanakan oleh semua elemen dengan bentuk pendampingan yang dilakukan berupa fisik dan non fisik. Non fisik diwujudkan melalui jasa fasiliasi, sedangkan fisik diwujudkan dengan pendampingan dana dari APBD Kabupaten Trenggalek.

Dalam implementasinya, Program PUMP-P2HP di Kabupaten Trenggalek telah dilaksanakan melalui beberapa tahapan diantaranya Sosialisai dan koordinasi kegiatan; Identifikasi, seleksi, verifikasi dan penetapan calon POKLAHSAR penerima PUMP-P2HP; Rekruitmen Tenaga Pendamping; Penyusunan dan pengusulan RUB dan dokumen administrasi; Penetapan kelompok penerima BLM PUMP-P2HP; Penyaluran BLM; Pemanfaatan BLM; Pendampingan; Monitoring dan evaluasi. Sehingga dapat dikatakan bahwa Dinas Perikanan telah memahami apa yang seharusnya dilaksanakan dalam mengimplementasikan Kebijakan Publik dimaksud, hal ini sesuai dengan konsep imlementaasi Kebijakan Sistem Rasional ( Top Down ) menurut George Edward III dalam Sadhana ( 2013 : 216).

Pendampingan

PUMP-P2HP dilakukan mulai dari (a) Pendampingan dana dari APBD Trenggalek, penumbuhan/pengembangan kelompok, (c) memfasilitasi kelompok dalam penyusunan RUB, (d) pendampingan pada saat pencairan sampai dengan pembelanjaan BLM, (e) melakukan pembinaan pasca program seperti bimtek, fasilitasi manajemen usaha, dan fasilitasi akses permodalan. Setelah Program PUMP-P2HP Tahun 2014 berakhir, pendampingan dilanjutkan berupa kegiatan pembinaan dan monev.

\subsubsection{Partisipasi Komunitas}

Partisipasi komunitas nampak dalam perencanaan dan pengawasan. Dari sisi perencanaan seluruh anggota berpartisipasi dalam penyusunan RUB dan perubahannya sesuai kebutuhan yang diinginkan kelompok yang telah disesuaikan dengan harga barang di pasaran dengan memperhatikan azas keadilan dan pemerataan. Semua anggota berhak untuk mengusulkan barang apa yang diperlukan sekaligus mendapatkan pembagian barang tersebut sesuai dengan kesepakatan. Partisipasi kelompok juga ada pada saat pembelanjaan BLM. Setelah rekening dicairkan, kelompok bisa langsung membelanjakan dana BLM yang diperoleh secara bersama-sama dengan anggota. Sedangkan dari sisi pengawasan, seluruh anggota kelompok melakukan pengawasan bersama melalui kegiatan kelompok seperti arisan, simpan pinjam dan pertemuan rutin kelompok. Kegiatan ini merupakan ajang kelompok untuk saling tukar informasi dan memecahkan masalah yang dialami para anggotanya.

\subsubsection{Pengorganisasian Kelompok}

Program PUMP-P2HP Tahun 2014 ini juga membangun rasa kekeluargaan, solidaritas dan kolektifitas masyarakat dalam bentuk kelompok masyarakat. Dengan adanya kelompok masyarakat ini diharapkan akan mempermudah mereka dalam mengakses sumberdaya yang dibutuhkan baik berupa sarana dan prasarana. Sebelumnya para pelaku usaha pengolahan dan pemasaran ini masih ada yang belum tergabung dalam satu kelompok. Mereka masih bekerja secara perorangan dengan sistem egosentris yang ditunjang dengan minimnya sarana, pengetahuan, permodalan. Dengan berkelompok akan memunculkan 
kegiatan kelompok dan memudahkan mereka untuk memperoleh bantuan.

Selanjutnya upaya yang dilakukan adalah penguatan kelembagaan baik berupa pembinaan, pendampingan dan pelatihan dari berbagai instansi terkait. Dengan penguatan kelembagaan ini diharapkan lembaga ini berdaya dan mandiri tanpa bergantung kepada bantuan Pemerintah saja sehingga mampu memainkan perannya sebagai motor penggerak ekonomi di wilayahnya masing-masing.

\subsubsection{Transparansi}

Dalam pelaksanaan kegiatan PUMP$\mathrm{P} 2 \mathrm{HP}$, prinsip transparansi diterapkan dalam pertanggungjawaban pengelolaan keuangan kelompok. Transparansi diwujudkan dalam bentuk kepemilikan buku rekening bersama atas nama kelompok.

\subsubsection{Sistem Pengawasan}

Dalam pelaksanaan PUMP-P2HP sistem pengawasan diterapkan dalam penggunaan dana BLM kelompok dan perkembangannya dikontrol secara bersama oleh seluruh anggota kelompok. Pengawasan yang dimaksud adalah pengawasan yang dilakukan oleh semua anggota kelompok. Seluruh anggota berhak untuk mengetahui besarnya dana yang diterima, dibelanjakan untuk apa saja dana tersebut, dibagikan untuk siapa saja barang yang dibelanjakan serta bagaimana pengelolaan sarana yang ada selanjutnya.

\subsubsection{Perspektif Gender}

Dalam implementasi PUMP-P2HP Tahun 2014, gender termasuk dalam salah satu indikator output pelaksanaan PUMPP2HP. Ditargetkan prosentase rata-rata anggota kelompok yang berjenis kelamin perempuan minimal $10 \%$ dari total anggota kelompok penerima. Dari data diketahui bahwa POKLAHSAR penerima BLM PUMPP2HP sudah beranggotakan perempuan lebih dari $40 \%$ dari total anggota. Bahkan ada satu kelompok yaitu Pasir Bahari yang anggota perempuan semua (100\%). Hal ini menunjukkan bahwa perempuan mulai diperhitungkan perannya di bidang sosial dan ekonomi.

Pemberdayaan perempuan dianggap sebagai salah satu alternatif solusi untuk mengatasi kemiskinan. Seperti yang dikatakan Sumarti, (2010 : 212) pemberdayaan perempuan dapat dilakukan melaui pemenuhan kebutuhan praktis yaitu dengan pendisikan, kesehatan, ekonomi baik perempuan maupun lai-laki dan melalui pemenuhan kebutuhan strategis yaitu dengan melibatkan perempuan dalam kegiatan pembangunan. Pemenuhan kebutuhan praktis dapat dilakukan dengan peningkatan sumber daya manusia ( pendidikan, kesehatan, ekonomi ). Sedangkan pemenuhan strategis dapat dilakukan dengan cara memperkuat kelembagaan ekonomi berbasis perempuan melalui peningkatan kapasitas kader-kader perempuan. Dalam tahapan penerimaan BLM PUMP-P2HP perempuan berperan aktif dalam kelompok mulai perencanaan hingga pengambilan keputusan seperti dalam penyusunan RUB, Perubahan RUB, pembelanjaan maupun penyusunan laporan perkembangan usaha.

\subsection{Faktor-faktor pendukung dan penghambat Implementasi Program PUMP-P2HP Tahun 2014 di Kabupaten Trenggalek}

Faktor yang menjadi pendukung implementasi program PUMP-P2HP Tahun 2014 antara lain :

1. Komunikasi yang baik antara pembuat kebijakan (Kementerian Kelautan dan Perikanan) dengan implementor di tingkat Provinsi ( Tim Pembina ) maupun di tingkat Kabupaten ( Tim Teknis ), karena di tingkat Kabupaten sudah melaksanakan identifikasi, seleksi, verifikasi, pengusulan, penetapan, sosialisasi, penyaluran, pembinaan dan monev;

2. Komunikasi antara Dinas Perikanan Kabupaten Trenggalek dengan Tenaga Pendamping juga terjalin harmonis;

3. Komunikasi antara Dinas Perikanan Kabupaten Trenggalek dengan Kelompok Pengolah dan Pemasar juga terjalin harmonis;

4. Komunikasi yang baik antara Tim Teknis dengan koordinator lapang dari 
partai yang mengemban aspirasi masyarakat;

5. Sumber Daya utamanya ditingkat Kabupaten sangat mendukung karena staf bidang pengelolaan hasil perikanan yang terlibat punya dedikasi cukup tinggi dan berkompeten ( sarjana perikanan );

6. Tersedianya dana pendamping dari APBD Trenggalek untuk mendukung kelancaran program.

Faktor- faktor yang menjadi penghambat implementasi Program PUMP-P2HP Tahun 2014 antara lain :

1. Pada awalnya kelompok pengolah dan pemasar yang ditunjuk oleh Kementerian Kelautan dan Perikanan merupakan kelompok aspirasi dan belum memiliki usaha di bidang perikanan, namun dengan adanya koordinasi yang baik antara Pusat, Provinsi, Dinas Kabupaten, Koordinator Lapang ( dari aspirasi ), kelompok ini diganti dengan kelompok binaan dari Dinas Kabupaten yang bisa memenuhi ketentuan. Proses penggantian ini memakan waktu yang panjang, sehingga menyebabkan tahap pengusulan sampai dengan pencairan ikut mundur;

2. Lamanya jangka waktu antara penyusunan Rencana Usaha Bersama (RUB) dengan pencairan BLM, sehingga menyebabkan ada beberapa barang yang harga nya naik mengikuti harga pasaran. Hal ini menyebabkan pembelanjaan peralatan tidak sesuai dengan kebutuhan dan pemerataan;

3. POKLAHSAR kurang mengetahui perkiraan harga peralatan pengolahan maupun pemasaran ikan yang dijadikan sebagai acuan dalam penyusunan RUB.

4. Kurang tertibnya POKLAHSAR dalam mengelola administrasi kelompok

\section{E. KESIMPULAN DAN REKOMENDASI}

\subsection{Kesimpulan}

Berdasarkan analisis dan pembahasan hasil penelitian sebagaimana dijelaskan bab terdahulu, maka dapatlah ditarik kesimpulan sebagai berikut :
1. Implementasi Program PUMP-P2HP sudah mengacu kepada 6 elemen pemberdayaan yaitu pendampingan, partisipasi komunitas, pengorganisasian kelompok, transparansi, sistem pengawasan dan perspektif gender.

2. Faktor-faktor yang mendukung keberhasilan Program PUMP P2HP Tahun 2014 di Kabupaten Trenggalek antara lain :

a. Komunikasi dan hubungan yang baik antara pembuat kebijakan dan pelaku;

b. Tenaga pendamping kelompok yang bisa diandalkan;

c. Sumber Daya utamanya ditingkat Kabupaten sangat mendukung karena staf bidang pengelolaan hasil perikanan yang terlibat punya dedikasi cukup tinggi dan berkompeten ( sarjana perikanan );

d. Tersedianya anggaran yang disediakan Pemerintah sebesar Rp. 30.000.000,- (Tiga Puluh Juta Rupiah) setiap kelompok untuk dibelanjakan sesuai kebutuhan kelompok.

e. Sikap pelaksana kebijakan yang sangat mendukung kegiatan juga menjadi faktor pendukung keberhasilan pelaksanaan program PUMP P2HP di Kabupaten Trenggalek.Komunikasi yang baik antar pelaksana kebijakan;

Sedangkan faktor-faktor yang menghambat keberhasilan Program PUMP P2HP Tahun 2014 di Kabupaten Trenggalek antara lain :

a. Proses identifikasi dan verifikasi kelompok baru pengganti kelompok aspirasi, sehingga menyebabkan tahap pengusulan sampai dengan pencairan ikut mundur;

b. Lamanya jangka waktu antara penyusunan Rencana Usaha Bersama (RUB) dengan pencairan BLM, sehingga ada beberapa barang yang harga nya naik mengikuti harga pasaran. Hal ini menyebabkan pembelanjaan peralatan tidak sesuai dengan kebutuhan dan pemerataan;

c. Kurang tertibnya POKLAHSAR dalam mengelola administrasi kelompok 


\subsection{Rekomendasi}

Berdasarkan kesimpulan yang ditulis, maka penulis menyampaikan saran-saran sebagai berikut :

a. Diharapkan program ini berlanjut terus dari tahun ke tahun dengan alokasi penerima yang berbeda. Namun program ini berhenti di tahun 2014, di tahun berikutnya sudah tidak ada program seperti ini lagi;

b. Keterbatasan akses pemasaran menyebabkan harga tidak stabil.

c. Diperlukan program penguatan kelembagaan terlebih dahulu agar bisa tumbuh secara mandiri dan berkelanjutan;

d. Agar terus melaksanakan monitoring dan evaluasi (monev) dan pembinaan kepada kelompok penerima bantuan Program PUMP-P2HP, untuk melihat sejauh mana perkembangan usaha dan kemandirian kelompok.

\section{F. REFERENSI}

Ife, Jim. 1995. Community Development : Creating Community Alternatives - Vision, Analysis and Practice. Australia : Longman

Keputusan Menteri Kelautan dan Perikanan Republik Indonesia Nomor KEP.14/MEN/2012. Pedoman Umum Penumbuhan dan Pengembangan Kelembagaan Pelaku Utama Perikanan

Kusnadi, 2003. Akar Kemiskinan Nelayan. Yogyakarta : LKiS Pelangi Aksara
Nugroho, Riant. 2008. Public Policy. Jakarta : PT Elex Media Komputindo.

Sadhana, Kridawati. 2013. Realitas Kebijakan Publik. Malang : UM PRESS

Suharto E, 2005. Membangun Masyarakat Memberdayakan Rakyat. Kajian Strategi Pembangunan Kesejahteraan Sosial dan Pekerjaan Sosial. Bandung : PT. Refika Aditama Sumarti

Widodo, J, 2012. Analisis Kebijakan Publik Konsep dan Aplikasi Analisis Proses Kebijakan Publik, Malang: Bayu Media

Winarno, Budi. 2012. Kebijakan Publik, Teori, Proses dan Studi Kasus. Yogyakarta : CAPS.

Peraturan Menteri Kelautan dan Perikanan Republik Indonesia Nomor PER.19/MEN/2010. Pengendalian Sistem Jaminan Mutu dan Keamanan Hasil Perikanan.

Keputusan Direktur Jenderal Pengolahan dan Pemasaran Hasil Perikanan Nomor KEP 35/DJ-P2HP/2014 tentang Pedoman Teknis Pengembangan Usaha Mina Pedesaan Pengolahan dan Pemasaran Hasil Perikanan Tahun 2014.

Kabupaten Trenggalek Dalam Angka Tahun 2016

Laporan PUMP-P2HP Tahun 2014 